\title{
Climate change and fossil fuel: An examination of risks for the energy industry and producer states
}

Jim Krane, Wallace S. Wilson Fellow for Energy Studies, Baker Institute for Public Policy, Rice University, Houston, Texas 77005, USA

Address all correspondence to Jim Krane at jkrane@rice.edu

(Received 9 December 2016; accepted 8 February 2017)

\section{ABSTRACT}

This article compiles and categorizes the various forms of climate risk facing the fossil fuel industry. The type and intensity of risk differs greatly among the three forms of fossil fuels, as well as between countries in the developing and developed world. The paper finds heightened risk for the coal industry and reduced risk for oil businesses, due to its lack of substitutes.

Burning coal, oil, and natural gas is the source of two-thirds of the world's emissions of greenhouse gases. Sales of these fuels also represent the economic underpinning of resource-rich countries and the world's largest firms. As such, steps taken to abate emissions undermine commercial opportunities to monetize fossil fuel reserves. Risks to the industry correlate with progress on climate goals.

This article analyzes recent literature on climate action strategy and finds that a new or intensified set of risks has arisen for the fossil fuel industry. These include government policies and legislation, financial restrictions among lenders and insurers, hostile legal and shareholder actions, changes in demand and geopolitics, as well as the onset of new competitive forces among states and technologies.

The exposure of carbon-based businesses to these risks and the potential for loss is neither distributed uniformly across the sector, nor adheres to a uniform time scale. Shareholder-owned firms in the developed world will be incentivized to react sooner than large state-owned resource owners in developing countries. The fates of the three fossil fuels also appear likely to play out differently. Demand for oil appears insulated by its lack of viable substitutes, while coal businesses are already undergoing climate-related action, pushed by decreasing social acceptance and constraining financial regulation. At the other end of the spectrum, climate action has improved the medium-term viability of low-carbon natural gas. What appears clear is that, as effects of climate change grow more pronounced, the industry faces a future that is less accepting of current practices.

Keywords: carbon dioxide; energy generation; fossil fuel; sustainability; transportation

\section{DISCUSSION POINTS}

- Commercial activity in fossil fuels is increasingly at odds with action to reduce the threat of climate change.

- The fossil fuel industry faces exposure to at least five distinct risk categories. Many businesses will change strategic direction to align activity with climate goals.

- The nature and intensity of risk differs greatly among the three fossil fuel types, as well as between the developing and developed world.

\section{Introduction}

Fossil fuel-producing businesses and governments find themselves in an intensifying predicament. Burning coal, oil, and natural gas is responsible for two-thirds of humanity's emissions of greenhouse gases or GHGs. A growing consensus of research concludes that most remaining fossil fuel reserves need to remain underground if humanity is to have a reasonable chance of weakening the advance of climate change. Rendering carbon as "unburnable" endangers business models based on carbon extraction. This includes some of the world's largest firms and economies of two dozen nation-states where exports of coal, oil or gas comprised more than $20 \%$ of 2014 GDP. ${ }^{1}$ 
Relief for the climate reduces commercial opportunity for the fossil fuel industry. Given the stakes, it bears asking: What, exactly, are the risks? How are they manifested and distributed? By Citicorp's estimate, resource abandonment on the scale required to meet the $2{ }^{\circ} \mathrm{C}$ threshold means forgoing $\$ 100$ trillion in fossil fuel revenues by $2050 .^{2}$ Following through on such a scale would constitute a disruptive force in global affairs, undermining national budgets and corporate balance sheets while exposing beneficiaries-including pension-holders and ordinary citizens of resource-exporting states-to the myriad risks outlined below.

Whether or not the world decarbonizes to the extent required ${ }^{3}$-and scholars assign a high probability that the $2{ }^{\circ} \mathrm{C}$ threshold will be surpassed ${ }^{4-6}$-climate action presents the fossil fuel industry with a new set of risks. These range from reduced wealth and influence for fossil fuel exporting countries; to stranded reserves of once valuable commodities; to various forms of divestment, whether on behalf of insurance companies, pension funds, or via tools allowing investors to purge portfolios of carbon exposure.

The risk burden is not shared uniformly among the three ${ }^{7}$ fossil fuel types. While much of the focus has been on oil companies and countries harboring large crude oil reserves, oil's place in the future energy mix appears relatively assured, due to the long-term nature of developing viable substitutes in the transportation sector. Coal, by contrast, faces a future of decreasing social acceptance and intensifying regulation, particularly in the developed world. At the other end of the spectrum, natural gas' lower carbon content positions it as a medium-term beneficiary of climate action. ${ }^{8}$

Further, decarbonization risks in the mature OECD economies differ from those in the developing world. In the OECD, where the fossil fuel trade is dominated by publicly traded companies, risks arise from government regulation and abatement actions, as well as shareholder activism. But shareholder-owned firms such as international oil companies (IOCs) also benefit from shorter reserves-to-production timeframes and flexible business models. Some are already adjusting operations to decrease vulnerability to climate action.

In the non-OECD countries, where growth in fossil fuel demand is high and where the largest pools of reserves are held, governments may act in opposite fashion, by protecting stateowned energy businesses from regulations and international pressure. However, the big national oil companies (NOCs) presiding over reserves with decades-long depletion horizons may be more exposed to declining demand and stranded assets. Decarbonization could thus spur geopolitical competition among producers, or even creation of opposing blocs of states which seek to enforce-or avoid-climate action.

\section{Risk types}

The taxonomy below outlines five main classes of climate risk for the fossil fuel industry:

(i) Policy risk: Government policies, regulations, and pledges that reduce carbon emissions; policies that support competing technology. (ii) Demand risk: Decline in global fossil fuel demand due to climate factors.

(iii) Financial risk: A broad category consisting of:

(a) Divestment risk: Shareholder or grassroots activism that seeks to influence producers through financial or reputational means.

(b) Portfolio risk: Investor avoidance of fossil fuel shares.

(c) Insurance risk: Antagonism from a business sector in which economic interests are aligned with climate action.

(d) Lending risk: Reduced availability of investment capital.

(e) Stranded asset risk: Commodity reserves or capital assets stranded prematurely.

(iv) Legal risk: Lawsuits based on liability for climate change.

(v) Geopolitical and Competition risk: Rivalry for market share among producers seeking to monetize reserves before they are stranded, and changing relations between countries based on decarbonization activity.

There are also physical risks to the industry from climate change itself. These include threats of damage from storms, rising heat intensity, and sea levels. ${ }^{9}$ Since physical risks can be expected to affect all businesses regardless of their carbon intensity, this paper does not delve into them.

This paper serves as a compilation of the risk types affecting fossil fuels, based on an in-depth study of recent literature. Beyond offering basic contextual analysis, I do not attempt to quantify risks, their effects on revenue, or their impact on accumulation of atmospheric carbon.

\section{Policy risk}

Policy risk is a broader category for what is typically known as regulatory risk. Governments around the world, including at the subnational level, have imposed myriad restrictions on fossil fuel use. Policy action probably poses the greatest risk of any outlined here, for two reasons. First, because many sources examined here-with few exceptions ${ }^{10}$-argue that economic competition alone will not enable noncarbon energy to replace fossil fuels. Second, because governments' options for intervention are broad. States can create and enforce laws ranging up to and including outright bans of fossil fuels. The government of Finland, for example, has proposed a complete ban on future use of coal in power generation. ${ }^{11}$

Policy risk includes government pledges such as the Intended Nationally Determined Contributions or INDCs from the 2015 Paris Agreement, as well as unrelated actions such as carbon taxes, cap-and-trade schemes, subsidies for substitute technologies, and regulations that hinder fossil fuel extraction, transportation, or intensity of use.

For the fossil fuel industry, the Paris climate agreement presents a large and uncertain source of policy risk: a global consensus on the need to turn away from fossil fuels that incentivizes regulation. 
Nearly every country on Earth has pledged to reduce its emissions in some way. If realized, these national pledges would reduce carbon emissions from a business-as-usual scenario by about 50 gigatons per year by 2050 , the yearly equivalent of leaving 23 billion tons of coal or 158 billion barrels of oil unburned. That level of reduction would restrict the increase in average temperature in 2100 to around $3{ }^{\circ} \mathrm{C}$ rather than $4{ }^{\circ} \mathrm{C}$ without INDCs. ${ }^{12}$ (Fig. 1) Deeper decarbonization is required to reach the $2{ }^{\circ} \mathrm{C}$ threshold.

INDCs approach decarbonization through policies tailored to local conditions. Former US President Barack Obama's pledge to reduce $\mathrm{CO}_{2}$ emissions by 26-28\% below 2005 levels by 2025 depends on retiring much of the US coal-fired power generation fleet and shifting toward natural gas and renewables. ${ }^{13}$ The Paris INDCs are nonbinding, however, and there is no enforceable penalty for ignoring them. US President-elect Trump has indicated that his administration may ignore the Paris pledge. Conflicting priorities between administrations in one country suggest the existence of large uncertainties around the implementation of decarbonization policies. Implementation uncertainty adds complexity to firms' response to climate policy, particularly in countries with decentralized systems and multiple veto wielders, or frequent changes in government.

\section{Carbon pricing}

Other forms of policy risk are embedded in carbon reduction policies include emissions trading schemes such as the European Union's Emissions Trading System, as well as carbon prices and taxes. For example, British Columbia's carbon tax is credited with a $13 \%$ reduction in per capita emissions and $16 \%$ cut in fossil fuel demand between 2008 and $2013 .{ }^{14}$

Carbon pricing is based on the notion that externalities, or social costs, should be included in prices for fuels and services. For example, if the costs to public health from emissions of sulfur dioxide, nitrogen oxides, and other coal pollutants were included in wholesale electricity prices, coal might be less

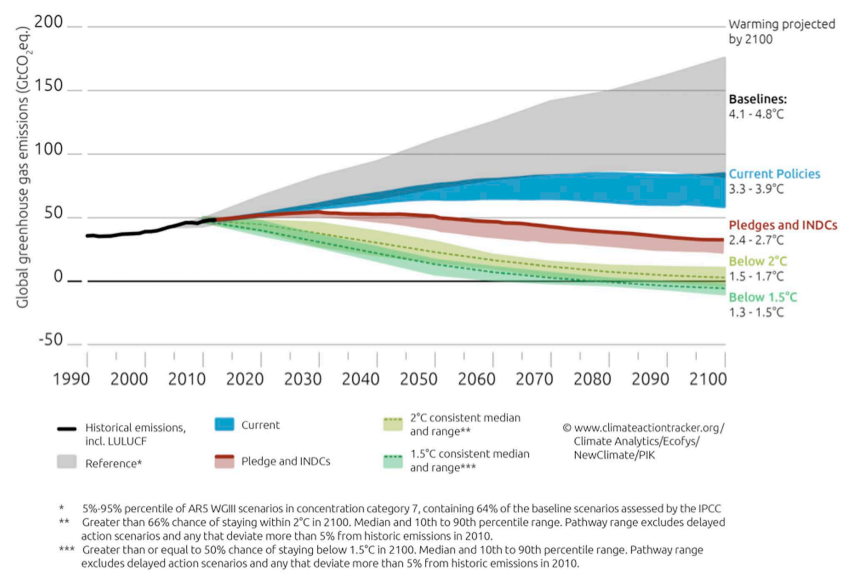

Figure 1. Forecast of effects of Paris pledges on future $\mathrm{CO}_{2}$ emissions. Source: Climate Action Tracker (used with permission). attractive than cleaner power generation fuels. Carbon pricing levies a cost for GHG emissions and the associated damage from warming temperatures, storms, loss of land and property use, and sea level rise. Implementation of carbon pricing is increasing in momentum. The World Bank estimates that $13 \%$ of global emission is already subject to a carbon price. If promises made at Paris are fully enacted, some 58\% of global GHG emission would be taxed (Fig. 2). ${ }^{15}$

Carbon prices range widely and some appear to have had little effect on fossil fuel demand. Demand for transportation, in particular, is highly price-inelastic and probably not very sensitive to moderate carbon pricing. In the United States, a 25-50\% increase in gasoline prices is required to reduce travel by $1 \%$, although the effect on fuel demand is stronger. ${ }^{16}$ Prominent forecasts of future demand incorporate assumptions for carbon pricing. Exxon Mobil's 2016 Outlook for Energy assumes carbon pricing in OECD countries reaches $\$ 80 /$ ton by 2040 . Despite the added cost of carbon and improvements in vehicle efficiency, Exxon expects oil demand will continue growing to 2040 , by an average of $0.7 \%$ per year. ${ }^{17}$

Demand for natural gas and particularly coal is more sensitive to taxation, since substitute technologies are available. The Exxon forecast predicts coal use dropping an average of $0.2 \%$ per year globally, while natural gas demand grows $1.6 \%$ per year. Noncarbon substitutes become more competitive and grow more quickly under carbon taxation, with growth

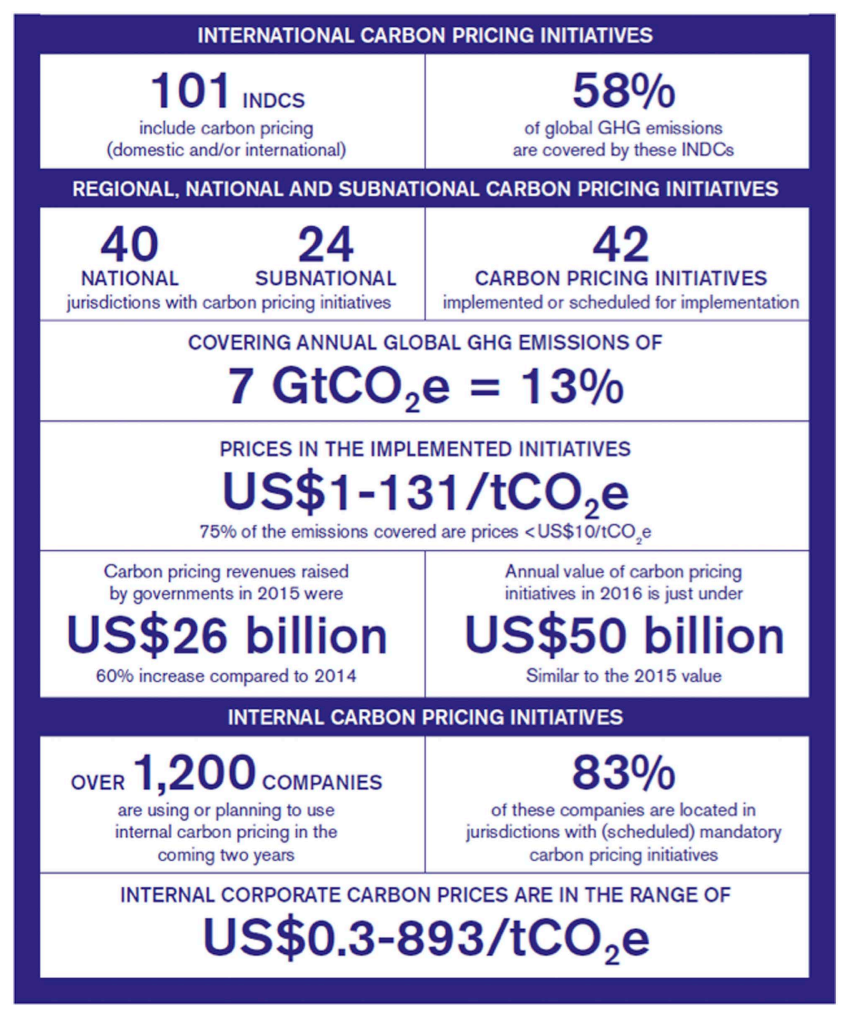

Figure 2. Global carbon emissions subject to international carbon pricing initiatives. Source: (World Bank 2016). 
averaging nearly $3 \%$ /year for nuclear and $5 \%$ for renewables (Fig. 3). ${ }^{17}$

In the future, policy risks for the fossil fuel sector could be globalized via the "climate club" scheme conceived by economist William Nordhaus. Countries would align carbon tax policies and impose border tariffs on "free riding" imports from countries where carbon is insufficiently regulated. ${ }^{18}$ Countries that avoid climate action would face border taxes on exports to countries in carbon-taxation blocs. Governments are thus incentivized to tax carbon so their exports receive preferential market access.

Anticarbon policies also include myriad other restrictions. These include bans on extraction methods-hydraulic fracturing for oil and gas ${ }^{19}$-and blocking of infrastructure projects, such as the Obama administration's denial of a permit for the Keystone XL pipeline. ${ }^{20}$ Government policies to encourage competing nonfossil sources could also thwart demand for fossil fuels. One example is the 2016 agreement between the governments of the United States, Canada, and Mexico to generate half of their electricity from carbon-free sources by $2025 .^{21}$

\section{Demand risk}

At some point, demand for fossil fuels will start to decline. The notion of "peak demand" is driven by the maturing of developing economies, particularly China's, and diversification beyond heavy industry into less energy-intense services. Demand risk is exacerbated by efforts to push economies toward noncarbon energy and higher efficiency.

Few believe that the world will reach peak energy demand anytime soon. But as climate policies come to the fore, governments will inevitably seek to meet some demand through cleaner energy. At the same time, noncarbon options are becoming viable replacements for retiring capital equipment, particularly in

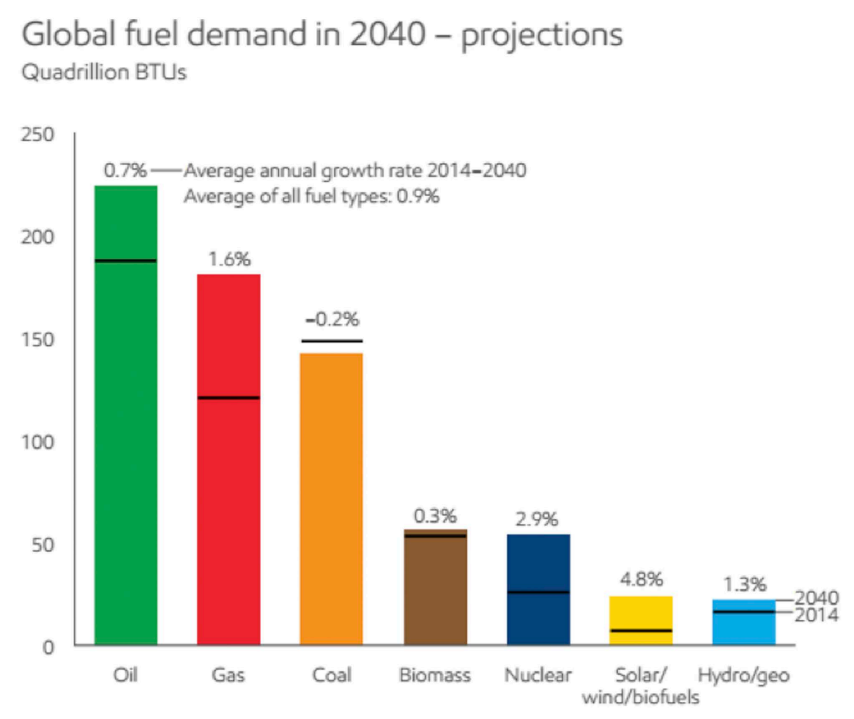

Figure 3. Global fuel demand in 2040_Projections. Source: Exxon Mobil 2016, used with permission. power generation. These forces are bound to affect demand for coal and, in the longer term, natural gas (Fig. 4).

Global coal consumption may have already peaked. In 2015 , global coal consumption dropped by 100 million metric tons, or $1.8 \%$, compared to 2014 levels. China, which consumes half of global coal, saw demand decline two years in a row, while U.S. coal consumption plunged nearly $13 \%$ in $2015 .{ }^{22}$ US coal production is forecast to fall another $15 \%$ in 2016 , reaching its lowest level since $1978 .^{23}$

The IEA's base case for coal demand is a $0.8 \%$ increase in yearly demand through 2020. But an alternate "peak-coal scenario" presents the possibility that global coal demand has peaked and will drop by $0.1 \%$ per year through $2020 .{ }^{24}$ The IEA sees 610 gigawatts (GW) of coal power generation capacity being retired for environmental reasons by $2025 .^{25}$

Natural gas is a different case. Due to its lower carbon content, gas is often described as a "bridge fuel" for a decarbonizing world. Gas turbine power plants can start up quickly and synchronize with intermittent renewables. However, when full lifecycle emissions for gas are included, gas' promise in mitigating climate change is less assured. ${ }^{26}$ The United States and Britain have both reduced their carbon footprints by switching from coal to gas. In 2015, gas and coal supplied equal $33 \%$ shares of total US power. By 2016, gas' share had grown to $34 \%$ while coal's slipped to $30 \%$ as a result of environmental action and a glut of cheap shale gas. ${ }^{27}$ Since much phased-out coal capacity will be replaced by gas, few observers believe that gas demand will peak anytime soon. Globally, gas is expected to surpass coal as a share of primary energy around $2030 .^{28}$

However, gas, like coal, has substitutes, including some that emit no carbon: nuclear, hydro, wind, and solar energy. Furthermore, the decarbonization that must occur to meet the $2{ }^{\circ} \mathrm{C}$ threshold does not allow gas to fully substitute for coal (Fig. 5).

Alternate scenarios are certainly possible. A 2016 report from Bloomberg New Energy Finance predicts that demand for all fossil fuels used in power generation will peak by 2025 and fall thereafter, chased out by wind and solar power with improved battery storage. By the late 2020s, the report argues, it will be

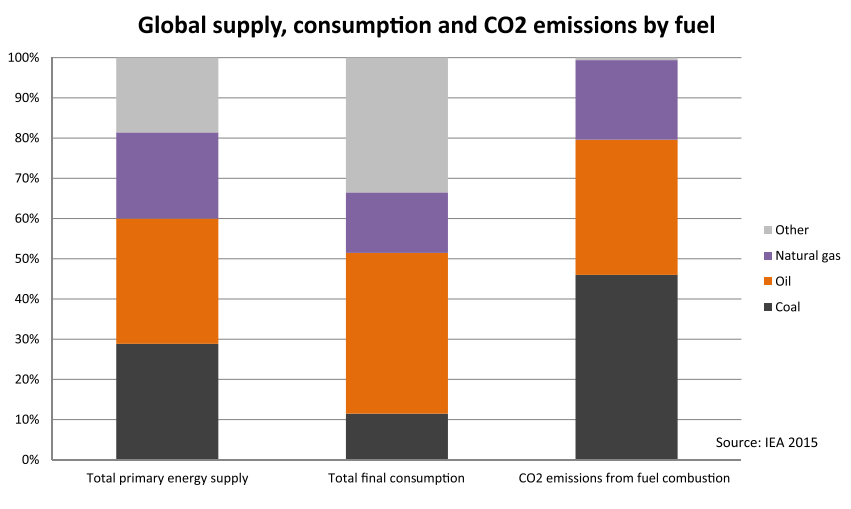

Figure 4. Supply, consumption, and $\mathrm{CO}_{2}$ emissions by fuel. Source: International Energy Agency, "World energy-related $\mathrm{CO}_{2}$ emissions," IEA Paris (online database) March 2016. Accessed January 31, 2017. 


\section{Carbon dioxide factors by fuel (EIA 2016)}

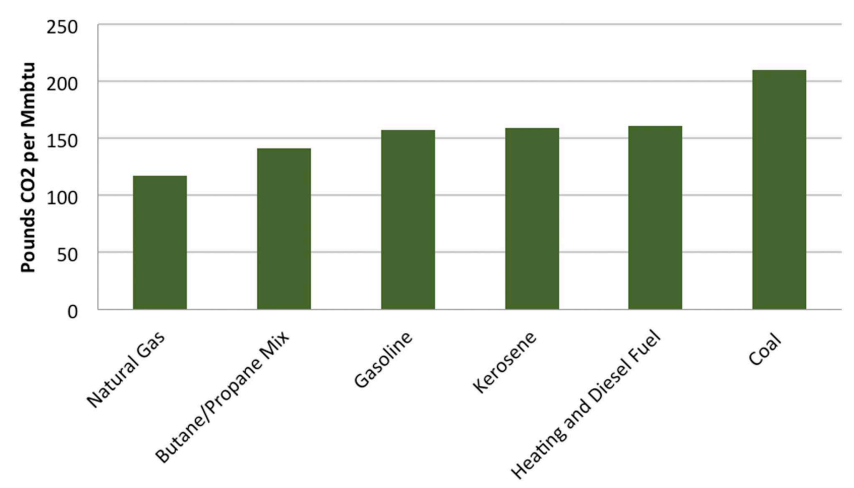

Figure 5. Carbon content of fossil fuels relative to energy output. Source: U.S. Energy Information Administration, 2016.

cheaper to build and operate a new renewable generation plant than to simply operate an existing coal or gas-fired plant. The crucial element is battery storage, which allows constant output from intermittent generators. ${ }^{10}$ However, other costs may reduce opportunities for early retirement of fossil fuel generation, including those associated with upgrades to electricity grids as well as stranded capital equipment.

What about oil? Two-thirds of the world's oil is consumed in transportation. As such, oil has few substitutes. Only electric vehicles and biofuels offer a reasonable replacement. These suffer from shortcomings, either in terms of energy density, cost per mile, range, and even carbon content. While electric vehicles and battery technologies are improving, so are internal combustion engines. The US Department of Energy forecasts that by $2040,99 \%$ of US transportation vehicles sold will operate on internal combustion engines. ${ }^{29}$ In short, oil is unlikely to lose its primacy in transportation without concerted government policies that impose heavy penalties on emissions or favor alternatives. ${ }^{30}$

Perhaps due to such factors, McGlade and Ekins forecast that oil reserves are the least exposed of the three fuels to abandonment by 2050 . Just a third of current conventional crude oil reserves would probably be abandoned in a successful $2{ }^{\circ} \mathrm{C}$ scenario, as opposed to half of gas and $82 \%$ of coal reserves. ${ }^{31}$

Even without a near-term competitive substitute technology, oil demand is still subject to decline. A 2016 report from Shell predicts that the world could see total oil demand reach its zenith as soon as 2021. ${ }^{32}$ The former Saudi oil minister, Ali Naimi, suggested peak oil demand may arrive by $2025 .{ }^{33}$ The IEA forecasts that gasoline demand may be nearing its peak, as efficiency gains and electric vehicles compensate for growth in the developing world. ${ }^{34}$ Exxon, meanwhile, sees no peak before 2040 , due to continued growth in diesel and petrochemical demand. ${ }^{35}$ McKinsey predicts that oil demand for transportation will peak by 2025 , but its use as a petrochemical feedstock will allow overall demand to increase slowly until $2050 .{ }^{36}$ While oil will inevitably peak at some point, most forecasts find that demand will tail off gradually, requiring companies to continue producing for decades.

Regardless, oil companies are under pressure to quantify exposure to demand risk and adjust business models to accommodate decarbonization. Academics have called for valuation methods for IOCs that rely on indicators other than booked reserves. ${ }^{37}$ Far greater exposure to long-term declines in demand confronts NOCs, which oversee about $97 \%$ of global oil reserves and $90 \%$ of production.

\section{Financial risk}

Financial risk is a broad category that covers the potential for higher costs or reduced revenues from five main sources, which are described below.

\section{Divestment risk}

In a 2015 speech, Bank of England Governor Mark Carney argued that climate change could precipitate a major selloff that could result in collapsed valuations. ${ }^{38}$ While that has not yet happened, shares in some fossil fuel companies are coming under scrutiny from investors worried about carbon intensity of earnings. Investor groups such as pension funds, religious organizations, ${ }^{39,40}$ insurance companies, and universities ${ }^{41}$ have shifted investments away from coal. A smaller number of campaigns have targeted oil and gas firms. Activist groups have begun publicizing carbon footprints as encouragement for firms to reduce emissions or shareholders to divest.

Some divestment is based on ethical concerns related to companies profiting while damaging the climate. Some is based on financial grounds, particularly on the likelihood that successful climate action will undercut commercial activity and share values. However, if climate action fails, asset risks may actually broaden. The Economist Intelligence Unit argues that entire portfolios and national economies face weaker returns based on the severity of warming. ${ }^{42}$

Other financial obstacles may compound the risk. These include banks' unwillingness to lend, legal liabilities from environmental damages, and capital assets devalued by premature shut down.

Divestment participants are among the largest institutional investors in the world, including, ironically, funds responsible for investing fossil fuel profits. The Norwegian Government Pension Fund, the world's largest hydrocarbon-based sovereign wealth fund with some $\$ 900$ billion in assets, decided in 2015 to divest from companies that received more than $30 \%$ of their revenues from coal. ${ }^{43}$ The Rockefeller Brothers Fund, based on the Standard Oil fortune, eliminated its holdings in coal and Canadian oil sands in 2014. ${ }^{44}$ In 2016, the related Rockefeller Family Fund announced it would sell off fossil fuel shares, including holdings of Exxon Mobil-once a part of Standard Oil-due to the company's public statements that were at odds with its internal understanding of climate change. ${ }^{45}$

Divestment has not usually damaged share prices or debt of targeted companies, since other investors tend to purchase shares that are sold. ${ }^{46}$ However, widespread shunning of coal 
shares is constraining the availability of financing and raising costs. By 2030 , divestment could reduce coal demand by a modest amount, around $2.5 \% .{ }^{47}$ In the oil business, divestment risk only poses a problem for shareholder-owned IOCs, not stateowned NOCs which dominate oil production.

A greater effect of divestment may be "stigmatization" that marks firms as targets for hostile regulation or other secondary effects. ${ }^{48}$ Activist groups have publicized carbon footprints and climate responsiveness among various industry sectors. A report from a group called BankTrack exposes lending to coal firms. The Asset Owners Disclosure Project ranks investment funds on climate criteria. A group called Fossil Free Indexes published what it described as the carbon footprint of the $\$ 300$ billion CalPERS state employee retirement fund. Had CalPERS directly owned the fossil fuel reserves implied by its share holdings, the pension fund would have ranked as the 55 th largest global oil and gas company and the 88th largest coal company, by reserves. ${ }^{49}$ The report argued that CalPERS' holdings exposed California pensioners to climate action risk, while also tarnishing CalPERS' environmental credentials.

Shortly after the report emerged, the California legislature passed a law forcing state pension funds to liquidate coal-related shares by $2017 .{ }^{50}$ As a result, CalPERS put pressure on companies in which it owned shares. ${ }^{51}$ The French utility giant, GDF Suez-now Engie-was threatened with divestment if it did not reduce its carbon footprint. ${ }^{52}$ In 2016 , Engie acted, selling its ownership in 17 US coal-fired power plants with $9 \mathrm{GW}$ of generating capacity, along with others in India and Indonesia, reducing its coal portfolio by a fifth, or 13 GW. ${ }^{53}$ Chairman Gerard Mestrallet said coal ran counter to the company's climate concerns, and pledged to stop building coal-fired power plants. Engie pulled out of another 2 GW in coal capacity it was negotiating in South Africa and Turkey. The firm is shifting its focus toward lower-emission renewables and natural gas projects. ${ }^{54}$

In the United States, coal has been hobbled by competition with cheaper natural gas, as well as declining steel production and regulatory uncertainty. Peabody Energy, the largest US coal mining firm, declared bankruptcy in 2016, preceded similar filings among coal producers Arch Coal, Alpha Natural Resources, Patriot Coal, and Walter Energy. US coal firms lost a combined 31,000 jobs and $\$ 30$ billion in share value since 2010. In 2016 , half of all US coal was being produced by bankrupt companies in the process of being broken up. ${ }^{55}$ Incoming President Donald Trump has declared support for a coal revival, but economic factors-and the probability of revived post-Trump regulationsubject US coal to most risk types outlined in this paper.

\section{Portfolio risk}

Stock exchanges and financial regulators have increased reporting requirements for firms to declare their carbon intensity and exposure to climate risk. ${ }^{56}$ Disclosures have made it easier for investors to avoid fossil fuel shares and tilt portfolios toward "green" indexes. In the United States, the Securities and Exchange Commission requires companies to disclose material risks from climate change and climate action in public filings.
These include impact of legislation and regulation on costs, profits, and demand; impact of international accords, including indirect effects such as decreased demand for carbon-intense products. $^{57}$

MSCI, a company that creates share indexes for investment managers, has developed new indexes and tools that exclude fossil fuel companies or highlight exposure to potential for stranded carbon assets. The company assists in rebalancing portfolios by "deliberately tilting more aggressively toward companies with large and growing renewable capacity". ${ }^{58}$ Likewise, Bloomberg's Carbon Risk Valuation Tool allows its clients to model the effects of scenarios such as "last ditch decarbonization" on their portfolios. ${ }^{59}$ HSBC provides clients with a similar climate risk analysis framework. ${ }^{60}$

Climate risk has thus led to the creation of "green" funds and other products that channel investment into firms that compete with fossil fuel companies.

\section{Insurance risk}

The global insurance business finds itself on the opposite side of the climate equation from fossil fuel firms. Insurers face increasing losses from climate change, due to the rising frequency of damaging weather events and subsequent payouts. The insurance sector is among those with the largest financial stake in climate progress. In 2016, UN Secretary General Ban Ki-moon urged insurers to anticipate and manage risks-including by decarbonizing investment portfolios used to pay future claimsso that the industry does not contribute to climate catastrophes that undermine its business. ${ }^{61}$

A further insurance risk has not yet materialized, but is under discussion. Insurers could refuse to provide coverage to coal firms-or the fossil fuel industry at large-as a way to hamper a business that is behind rising property damage claims. ${ }^{62}$

Climate risk is already influencing insurance portfolios. Climate-focused investor advisory group Ceres has tallied fossil fuel holdings worth $\$ 459$ billion among US insurance firms. ${ }^{63}$ Some are starting to divest. The California Insurance Commission has asked insurers operating in the state to divest from coal and to report holdings in oil and gas firms, including pipeline and transport companies. ${ }^{64}$

The French insurer AXA announced in 2015 that it would divest from its last remaining coal mining and utility assets, worth $\$ 560$ million, while shifting into "green" investments that have lower or beneficial climate impacts. AXA CEO Henri de Castries said climate-driven events already represented 15 to $20 \%$ of the firm's business risk. He said it had become "absolutely clear" that warming beyond $2{ }^{\circ} \mathrm{C}$ would make it "tougher and tougher and probably impossible" for insurers to cope with property damage. ${ }^{65}$ German insurer Allianz, with nearly $\$ 2$ trillion in holdings, announced it would reduce coal investment in favor of wind power. ${ }^{66}$

\section{Lending risk}

A related source of risk for fossil fuel companies is the drying up of financing. In 2013, the US Treasury Department announced that the United States would no longer support coal investment 
among multilateral institutions, although the US Export-Import Bank participates in coal projects in poor countries. ${ }^{67}$ In a similar process to divestment campaigns, activist groups have exposed lending to the coal sector ${ }^{68}$ and banks have begun stepping back. Bank of America, Citigroup, JP Morgan Chase, and Deutsche Bank have enacted climate-driven lending prohibitions on coal mining and power plants. Citigroup has mandated a "risk review" prior to lending to businesses in Canadian oil sands. ${ }^{69}$ Lending prohibitions shrink the pool of willing financiers, possibly forcing coal businesses to turn to more expensive sources. ${ }^{70}$

Elsewhere, Brazil's development bank BNDES has halted financing for coal- and oil-fired power plants. ${ }^{71}$ Japanese banks and export credit agencies, which financed big coalfired power plants in Mozambique and Vietnam in 2015, have since come under pressure to halt coal financing. ${ }^{72}$ As OECD banks depart the sector, Chinese lenders have captured the largest share of coal funding opportunities, including the top three spots (Fig. 6). ${ }^{73,74}$

\section{Stranded asset risk}

If climate action is effective, the OECD believes that assets will inevitably be stranded. ${ }^{48}$ Stranded asset risk is not unique to fossil fuels. Any industry might be hurt by advances in technology or customer preferences that render capital equipment underutilized or abandoned prior to the expected investment time horizon. Fossil fuel reserves are already routinely stranded, at least temporarily, by falling market prices. Climate risk is different. Governments, firms, individuals, and international organizations are actively pursuing actions that damage fossil fuel businesses irrespective of prices or availability of substitutes.

Recent estimates by McGlade and Ekins find that roughly $80 \%$ of known coal reserves must remain unburned if the $2{ }^{\circ} \mathrm{C}$ target is to be met. The authors find that carbon capture and storage technology is of little help, given its expense, the unwieldy parasitic load on power plants, and a lack of carbon pricing that

\section{Lending to global coal industry 2011-2014}

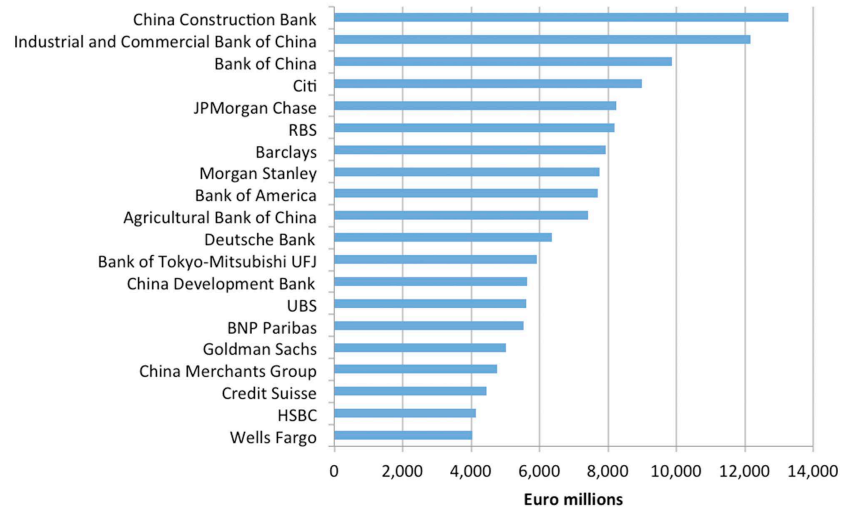

Figure 6. Top 20 banks and their lending to the global coal industry from 2011-April 2014, as reported by BankTrack. Source: BankTrack 2014. might incentivize its construction. Citicorp estimates that the mining and power industries will lose investments worth $\$ 11.5$ trillion over the next 25 years. ${ }^{75}$ (Table 1) Further, half of global gas reserves need to remain in the ground to meet the $2{ }^{\circ} \mathrm{C}$ target. ${ }^{31}$

Financial reports outline the potential for enormous losses in revenues, the risk of which increases relative to concentrations of carbon and the costs of extraction. The French bank Kepler Cheuvreux finds that adhering to the $2{ }^{\circ} \mathrm{C}$ carbon threshold would, by 2035 , leave the fossil fuel industry with $\$ 28$ trillion in lost revenues from stranded reserves. ${ }^{76}$ As mentioned, Citicorp estimates that the value of stranded fossil fuels will surpass $\$ 100$ trillion by 2050 . The New York bank believes that climate-inspired reductions in earnings should be considered when weighing creditworthiness of producer companies and countries. ${ }^{75}$

A similar "stranded assets" predicament is said to threaten long-term earnings potential of fossil-fuel based utilities. Electricity providers appear to be overbuilding generation infrastructure to the extent that capital stock will have to be retired prematurely if $\mathrm{CO}_{2}$ emissions are to be kept within the bounds of a $2{ }^{\circ} \mathrm{C}$ temperature increase. Complying with the $2{ }^{\circ} \mathrm{C}$ carbon budget requires that no new power generation plants be built after 2017 unless other infrastructure is retired early, underutilized, or retrofitted with carbon capture and storage technology. ${ }^{77}$

By 2035, myriad fossil-fuel assets could become "stranded," or unable to earn a financial return prior to the end of their economic lives. The IEA estimates some $\$ 300$ billion in unrecovered investments amid nearly $\$ 3$ trillion in yearly energy investment of all types the IEA has forecast over a similar period. ${ }^{78}$

(i) $165 \mathrm{GW}$ of fossil fuel power generation capacity with unrecovered sunk costs of $\$ 120$ billion.

(ii) Oil and gas exploration costs worth $\$ 180$ billion.

(iii) Some $\$ 4$ billion in unrecovered coal mine investment. ${ }^{79}$

Examined in this light, Japan's plans to build 49 new coalfired power plants with $28 \mathrm{GW}$ of capacity would create risk of stranded assets and write-downs worth at least $\$ 50$ bn under various scenarios, because-for environmental or cost competitiveness reasons-the plants would probably be retired before their 2070 investment time horizon. ${ }^{80}$

Should these sorts of forecasts affect share prices of publicly traded firms? A number of climate-based activist groups such as the Carbon Tracker Initiative and the Institutional Investors Group on Climate Change believe that they should, and that climate risks have not yet been priced into oil company stocks. ${ }^{81}$ The combined risks to the industry suggest the possibility of a "carbon bubble". This is the contested notion that market capitalizations of publicly traded companies are exaggerated because the enforcement of carbon targets may prevent them from producing the reserves they have booked.

However, climate risks are already priced into coal shares and probably into oil company shares. Share prices are based on investor assumptions of future earnings over a relatively short time horizon. Since climate effects accrue gradually and since 
Table 1. Dollar values of unburnable fossil fuels in a $2{ }^{\circ} \mathrm{C}$ scenario.

\begin{tabular}{|c|c|c|c|}
\hline Scenario & $\begin{array}{l}\text { Value of unburnable } \\
\text { oil (in trillion USD) }\end{array}$ & $\begin{array}{l}\text { Value of unburnable } \\
\text { gas (in trillion USD) }\end{array}$ & $\begin{array}{l}\text { Value of unburnable } \\
\text { coal (in trillion USD) }\end{array}$ \\
\hline With CCS & 30 & 22 & 57 \\
\hline Without CCS & 25 & 24 & 62 \\
\hline
\end{tabular}

Note: Assumes $\$ 70$ per barrel of oil, $\$ 6.5$ per MMBTU of gas and $\$ 70$ per metric ton of coal.

Source: Citi Research, McGlade and Ekins (2015).

IOCs hold just five to 15 years of proved reserves, investors are probably betting that production of booked reserves is unlikely to be upended by climate concerns. Analysts and oil company officials have stated that long-term effects of climate on their business models are a different issue than investor expectations for short-term earnings. ${ }^{82}$ The transition away from fossil fuels, in particular oil and gas, is a gradual process that is being incrementally priced in by markets. ${ }^{83}$ For IOCs, climate risk looks more threatening over the long term, possibly affecting the value of future reserves. ${ }^{84}$

For producer countries like Saudi Arabia or Kuwait, where reserves can support current production for another 50-100 years, successful climate action probably will render some underground reserves unburnable. Of course, a rapid shift in technology that renders fossil fuels obsolete could have the same effect on asset values.

Opposite cases are also possible: energy shares could get a boost from a breakthrough that allows carbon-rich fuels to be exploited without harming the climate. Fossil fuels might also get a reprieve from large-scale adoption of geoengineering techniques that intervene in the Earth's climate system to reverse the greenhouse effect. ${ }^{85}$ And, as mentioned above, there is a high likelihood that humanity will fail to attain the $2{ }^{\circ} \mathrm{C}$ carbon budget, which pushes climate risk into the future.

\section{Legal risk}

Legal scholars have long argued that the fossil fuel industry can be held liable for effects of its emissions. Basis for claims extends from compensation for weather damage to property or rising insurance premiums, to broader liability over lost land use, damage to national economies and public health. ${ }^{86-88,90}$ Expectation of intensifying climate regulation in the future increases the probability of lawsuits. ${ }^{89}$ Suits could be brought by individuals, class-action groups, businesses, or governments; potential targets include single firms, industry groups, and governments. ${ }^{92}$

Improved links between GHG emissions and extreme weather events will intensify legal risk. Tort law and public nuisance law could be a basis for transferring costs to entities that can be shown to have contributed to cause the damage. ${ }^{90}$ Other legal actions could focus on producer countries, which could conceivably be sued by victim states in international courts. In 2015 , a group of US citizens sued the US government for exacerbating risks to "life, liberty, and property" by enabling or allowing $\mathrm{CO}_{2}$ emissions to accumulate in the atmosphere, despite an understanding of the risk. ${ }^{91}$ A case study of a single US coalfired power plant estimated the plant's liability for climate disasters at $\$ 368$ million. ${ }^{92}$

Likely litigation targets will be "deep-pocketed corporations" that could face class-action suits similar to the successful campaign against the tobacco industry. ${ }^{89}$ Legal action could also stem from damage to livelihoods of people and businesses in coastal areas threatened by rising seas. Scholars disagree about whether establishing individual liability would be an obstacle ${ }^{89}$ or whether it is unnecessary. Allen argues that, in the absence of direct evidence, litigation could be based on "mean likelihood-weighted liability" that an industry's activity exacerbated the damage. ${ }^{93}$

\section{Geopolitical and competition risk}

Competition among technologies, companies, and producer countries has always been a source of risk in the oil and gas industry. Climate change intensifies the competitive environment. In general, the lower a resource's cost and carbon content, the more competitive it will be in a climate-constrained market. Big producers face a significant drop in revenues from adherence to a $2{ }^{\circ} \mathrm{C}$ carbon budget, with NOCs most affected.

\section{Market risk and the green paradox}

Climate change could exacerbate competition for market share by encouraging price war behavior. If oil producers believe climate restrictions might lead to stranded assets, they may decide to step up production to reduce risk exposure. Sinn has labeled the phenomenon "the green paradox", arguing that environmental policies that restrict carbon emissions have the perverse effect of accelerating fossil fuel production, thus exacerbating carbon emissions and global warming. ${ }^{94}$

It is possible that the green paradox is already affecting energy markets. OPEC members Saudi Arabia, Kuwait, and the United Arab Emirates-holders of some of the largest and lowestcost oil reserves-had until recently favored long-term depletion strategies that limited production and propped up market prices. This future-oriented strategy allowed greater participation by higher-cost producers outside OPEC. But the cartel's future orientation appears to have diminished. Since November 2014, OPEC-led by Saudi Arabia-has emphasized retaining a share of the oil market rather than sustaining high prices. Despite an 
OPEC agreement to cut production in late 2016, Saudi Arabia continued to maintain production at historic highs at the time of writing, pushing higher-cost oil from the market. The Saudi change in strategy was probably driven by rising competition with US shale and other non-OPEC oil.

However, if the Saudis worried that reserves might someday be stranded, they might behave the same way, increasing current production in hopes of reducing the amount of resources abandoned in the future. ${ }^{95}$

Curtailment of future oil demand would be disastrous for Saudi Arabia, Venezuela, and other large producer states, few of which have diversified economies ready to move beyond oil. By increasing production and pushing down market prices, they might shift the risk of stranded assets to higher-cost players, including shareholder-owned IOCs. The same phenomenon could be affecting coal producers. For them, selling at a discount is preferable to seeing reserves stranded. By encouraging stepped-up production, the climate threat to fossil fuels can perversely lead to cheaper, more attractive fossil fuels. Over the long term, cheaper prices could destabilize producer economies and trigger social unrest.

\section{Other geopolitical risks}

A global transition away from fossil fuels represents a major disruptive force in international relations. Declining demand for oil could diminish the strategic importance of petro-states. In turn, importing countries might find themselves less committed to guaranteeing external security and regime survival in exporting countries. One potential casualty might be the US Carter Doctrine, which declares that the United States will use military force to protect oil exporting states in the Persian Gulf. If the global economy grows less dependent on energy sourced in the Gulf, the United States may feel less compelled to spend some $\$ 50$ to $\$ 100$ billion per year ${ }^{96}$ in protecting its allies in the region.

State-to-state competition could assume more dangerous form. A "green paradox" battle for oil rents could evolve into a quest to shut down competing resources. Verbruggen and Van de Graaf argue that an era of oversupply would incentivize producer states to prevent competitors from producing oil. Actions could range from embargoes to sponsoring armed intervention or terrorism, all of which would be aimed at creating chaos in producing countries, so reserves cannot be produced. ${ }^{97}$

Finally, if decarbonization proceeds on a two-speed track, with developed countries acting to reduce emissions while developed countries engage in carbon-intense industrialization, relations between the OECD and non-OECD could worsen. Developed states could take on a quasienforcement role, imposing restrictions on trade and multilateral funding. Climate action could thus create a new arena for geopolitical competition among opposing blocs.

\section{Conclusion}

As climate change effects grow more pronounced, there can be little doubt that an industry that produces $68 \%$ of human GHG emissions will find itself under increasing pressure. The risks to the industry correlate with progress on climate goals. Unless a technological breakthrough can restrict carbon releases, the fortunes of the fossil fuel industry and the stability of Earth's climate will be locked in a zero-sum game. Climate's gain is the industry's loss and vice versa.

For coal, the threats posed by climate action are already being felt. Coal's fortunes now rest with developing countries, where decisions to seek China-style, coal-led development will be met by increasing international pressure to choose an alternate path. Mainstream banking has moved away from coal, and new investments are falling to banks in China and Japan. These institutions will come under similar pressure and can be expected to act to avoid reputational damage.

Climate threats to natural gas demand appear further afield, given the fuel's reduced carbon content. Many anticarbon policies that target coal cede market share to gas. Longer term, however, gas is vulnerable to replacement by lower-carbon substitutes.

Oil, by contrast, is insulated by its unique role in transportation. This does not mean oil firms will be unaffected. Expectations of escalating restrictions encourage increases in current production. Environmental regulation could, through the "green paradox", lead to lower oil prices, increased demand, and gains in market share by low-cost producers like Saudi Arabia at the expense of higher cost ones like those in North America. Since upstream oil investments are typically based on 20- or 30-year time horizons, one must accept the possibility that financial returns will be affected by climate action.

Further, competition among producers for market share will be complemented by competition between fossil fuels and renewables. Divestment and policy risks will magnify the challenges. Insurance companies and other threatened sectors can be expected to press for stronger action. Institutional investors and individuals will reward companies based on "future proofing" and penalize those deemed too exposed to carbon.

Despite these pressures, it bears remembering that energy transitions play out over many decades. ${ }^{98}$ As such, arguments that IOCs face a near-term "carbon bubble" are probably overplayed, particularly if decarbonization is left to market forces. Stranding of reserves, particularly of crude oil, is most likely to be a factor of government policy, risks of which are difficult to forecast. IOCs may weather the climate storm more deftly than fossil fuel-dependent producer countries by modifying business lines. Just as IBM has shifted from computer hardware to services, IOCs are altering their strategic direction. Shell's acquisition of BG emphasizes a shift from upstream oil toward natural gas. Total has bet on renewables and battery storage. Exxon Mobil is moving into petrochemicals, a process which locks $\mathrm{CO}_{2}$ inside products rather than burning it. ${ }^{99}$ Arguably, states with ingrained political structures based on oil exports will have a harder time adapting. ${ }^{100}$

It is clear that carbon-based businesses and economies face increasing impediments to the consumption of their products. Whether through taxes, legal restrictions, moral arguments, favoritism for competitors, or hampered access to financial markets, the industry faces a future that is less accepting of current 
practice. Some businesses and perhaps some governments, will not survive.

Going forward, as climate transformation intensifies, intervention can be expected to strengthen. Countries and firms that pursue decarbonization strategies reduce their exposure to risks outlined above. In many instances, first mover advantage has already been taken. Companies and states that delay may find fewer opportunities and intensified competition.

\section{Summary}

The article reviews recent literature on the potential effects of climate change action on the fossil fuel industry. Categories of climate actions examined include government policies and legislation, financial practices and regulations including restrictions in lending and insurance, changes in demand and geopolitics, as well as the onset of new competitive forces. The article concludes that risk exposure differs greatly among the three fossil fuel types, as well as among opportunities in the developing and developed world. It finds heightened risk for coal industry and reduced risk for oil businesses, due to its lack of substitutes.

\section{Acknowledgments}

The author would like to thank the three anonymous peer reviewers, as well as Mari Luomi at the Emirates Diplomatic Academy, Rob Minter of Engie, and Rice University's Michael Maher, Anna Mikulska, and Elsie Hung for their input and commentary on this manuscript.

\section{NOTES AND REFERENCES:}

1. World Bank: Total Natural Resources Rents (\% of GDP) 2014, World Development Indicators (2015).

2. Citi GPS: Energy Darwinism II: Why a Low Carbon Future Doesn't Have to Cost the Earth (Citicorp Global Perspectives \& Solutions, 2015). Available at: https://www.privatebank.citibank.com/home/fresh-insight/ gps-energy-darwinism.html (accessed January 31, 2017).

3. Keeping warming within the $2{ }^{\circ} \mathrm{C}$ threshold is generally accepted as preventing atmospheric carbon from rising from its current level of 400 parts per million to extend beyond 450 parts per million.

4. Carraro C. and Massetti E.: The improbable $2 \mathrm{C}$ global warming target. Sito Vox (Centre for Economic Policy Research, 2009). Available at: http:// voxeu.org/article/improbable-2-c-global-warming-target (accessed January 31, 2017).

5. Riahi K., Kriegler E., Johnson N., Bertram C., Den Elzen M., Eom J., Schaeffer M., Edmonds J., Isaac M., and Krey V.: Locked into Copenhagen pledges-implications of short-term emission targets for the cost and feasibility of long-term climate goals. Technol. Forecast. Soc. Change 90,8 (2015).

6. Schleussner C-F., Rogelj J., Schaeffer M., Lissner T., Licker R., Fischer E.M., Knutti R., Levermann A., Frieler K., and Hare W.: Science and policy characteristics of the Paris Agreement temperature goal. Nat. Clim. Change 6, 827-835 (2016).

7. For purposes of simplicity, hard coal and lignite are lumped together, as are crude oil and natural gas liquids.

8. The IEA sees natural gas demand rising by $30 \%$ by 2030 , partly due to climate action. See: International Energy Agency: Energy and Climate Change. World Energy Outlook Special Report (IEA, Paris, 2015); p. 38. Available at: https://www.iea.org/publications/freepublications/ publication/WEO2015SpecialReportonEnergyandClimateChange.pdf (accessed January 31, 2017).
9. Krane J.: Floods, Wildfires, Extreme Heat: Is the Climate Fighting Back Against the Fossil Fuel Industry? (Forbes, 2016). Available at: http://www. forbes.com/sites/thebakersinstitute/2016/08/19/floods-wildfiresextreme-heat-is-the-climate-fighting-back-against-the-fossil-fuelindustry/\#746e90025263 (accessed January 31, 2017).

10. Bloomberg New Energy Finance: New Energy Outlook 2016 (2016). Available at: https://www.bloomberg.com/company/new-energy-outlook (accessed 31 January 2017).

11. Helsinki Times: Finland on Its Way to Become World's First Country to Ban Coal Use in Energy Production (2016). Available at: http://www. helsinkitimes.fi/finland/finland-news/domestic/14333-finland-on-itsway-to-become-world-s-first-country-to-ban-coal-use-in-energyproduction.html (accessed January 31, 2017).

12. Climate Action Tracker: Available at: http://climateactiontracker.org/ global.html (accessed January 31, 2017). Individual pledges have been cataloged on the Carbon Tracker website.

13. Columbia University Earth Institute: What is the U.S. Commitment in Paris? (2015). Available at: http://blogs.ei.columbia.edu/2015/12/11/ what-is-the-u-s-commitment-in-paris (accessed January 31, 2017).

14. See: World Bank Climate Change blog: British Columbia's carbon tax shift: An environmental and economic success (2014). Available at: http://blogs. worldbank.org/climatechange/british-columbia-s-carbon-tax-shiftenvironmental-and-economic-success (accessed January 31, 2017); Also: "British Columbia/Canada", Carbon Tax Center, (undated). http://www. carbontax.org/where-carbon-is-taxed/british-columbia (accessed January 31, 2017).

15. World Bank: State and Trends of Carbon Pricing 2016. Research Report (World Bank, Washington, 2016). Available at: https://openknowledge. worldbank.org/handle/10986/13334 (accessed January 31, 2017).

16. US Energy Information Administration: Gasoline Prices Tend to Have Little Effect on Demand for Car Travel (2014). Available at: http://www.eia.gov/ todayinenergy/detail.php?id=19191 (accessed January 31, 2017).

17. Exxon Mobil: Global fuel demand in 2040-Projection. In The Outlook for Energy: A View to 2040. Slide presentation (2016); p. 57. Available at: http://cdn.exxonmobil.com/ /media/global/files/outlook-forenergy/2016/2016-outlook-for-energy.pdf (accessed January 31, 2017).

18. Nordhaus W.D.: A new solution: The climate club. In New York Review of Books (2015). Available at: http://www.nybooks.com/articles/2015/ 06/04/new-solution-climate-club/ (accessed January 31, 2017).

19. Most "fracking bans" are not driven primarily by a wish to reduce GHG emissions. Neither have the bans shut-in ongoing production. They have thus far only restricted future opportunities. See: Kenneth B. Medlock III: The Land of Opportunity? Policy, Constraints, and Energy Security in North America. Baker Institute research paper (2014). Available at: http://bakerinstitute.org/media/files/files/94020ec4/CES-PubEnergySecurity-060214.pdf (accessed January 31, 2017).

20. Lemphers N.: The Climate Implications of the Proposed Keystone XL Oilsands Pipeline (Pembina Institute, 2013).

21. Dlouhy J.A. and Greiling Keane A.: U.S., Mexico, Canada pledge 50 percent clean Power by 2025 (Bloomberg, 2016). Available at: http://www. bloomberg.com/news/articles/2016-06-27/u-s-mexico-said-to-pledge50-percent-clean-power-by-2025 (accessed January 31, 2017).

22. BP p.l.c.: BP Statistical Review of World Energy 2015 (BP, London, 2016).

23. US Energy Information Administration:Coal forecast. Short Term Energy Outlook (2016). Available at: http://www.eia.gov/outlooks/steo/report/ coal.cfm (accessed January 31, 2017).

24. International Energy Agency: Coal. Medium-Term Market Report 2015 (2015). Available at: http://www.iea.org/newsroomandevents/ pressreleases/2015/december/global-coal-demand-stalls-after-more-thana-decade-of-relentless-growth.html (accessed January 31, 2017).

25. International Energy Agency: Re-Powering Markets: Market design and regulation during the transition to low-carbon power systems (International Energy Agency, 2016), p. 31.

26. Emissions stem from transport, compression, liquefaction and leaking methane, itself a powerful greenhouse gas. In Handbook of Clean Energy Systems, Volume 6, edited by Jinyue Yan (Wiley, Chichester, 2015); pp. 3517-3544. 
27. Note that coal's share is expected to rebound slightly in 2017. See: Short-Term Energy Outlook (US EIA, 2016); p. 2.

28. BP Energy Outlook 2016: Outlook to 2035. Slide presentation; see slide 14 (2016). Available at: https://www.bp.com/content/dam/bp/pdf/ energy-economics/energy-outlook-2016/bp-energy-outlook-2016.pdf (accessed January 31, 2017).

29. US Department of Energy: Advancing Clean Transportation and Vehicle Systems and Technologies: Internal Combustion Engines, Quadrennial Technology Review 2015 (2015); p. 1. Available at: http://energy.gov/ sites/prod/files/2015/11/f27/QTR2015-8C-Internal-CombustionEngines.pdf (accessed January 31, 2017).

30. Covert T., Greenstone M., and Knittel C.R.: Will we ever stop using fossil fuels? J. Econ. Perspect. 30(1), 117 (2016).

31. McGlade C. and Ekins P.: The geographical distribution of fossil fuels unused when limiting global warming to $2{ }^{\circ} \mathrm{C}$. Nature 517(7533), 187 (2015).

32. Katakey R.: Energy Giant Shell Says Oil Demand Could Peak in Just Five Years (Bloomberg, 2016). Available at: https://www.bloomberg.com/ news/articles/2016-11-02/europe-s-biggest-oil-company-thinks-demandmay-peak-in-5-years (accessed January 31, 2017).

33. Waldman P.: Saudi Arabia's Plan to Extend the Age of Oil (Bloomberg, 2015). Available at: http://www.bloomberg.com/news/articles/ 2015-04-12/saudi-arabia-s-plan-to-extend-the-age-of-oil (accessed January 31, 2017).

34. Blas J. and Blewitt L.: Tesla Shock Means Global Gasoline Demand Has All But Peaked (Bloomberg, 2016). Available at: https://www.bloomberg.com/ news/articles/2016-11-22/the-tesla-shock-global-gasoline-consumptionhas-all-but-peaked (accessed January 31, 2017).

35. Exxon Mobil's "Outlook for Energy: A View to 2040" finds no "peak" and projects average oil demand growth of $0.7 \%$ per year to 2040 . Available at: http://cdn.exxonmobil.com/ /media/global/files/outlook-for-energy/ 2016/2016-outlook-for-energy.pdf (accessed January 31, 2017).

36. Roelofsen O., Sharma N., Sutorius R., and Tryggestad C.: Is Peak Oil Demand in Sight? (McKinsey, 2016). Available at: http://www.mckinsey. com/industries/oil-and-gas/our-insights/Is-peak-oil-demand-in-sight (accessed January 31, 2017).

37. Stevens P.: International Oil Companies: The Death of the Old Business Model (Chatham House, London, 2016).

38. Carney M.: Breaking the Tragedy of the Horizon-Climate Change and Financial Stability. Speech given at Lloyd's of London (2015). Available at: http://www.bankofengland.co.uk/publications/Pages/ speeches/2015/844.aspx (accessed January 31, 2017).

39. Green Faith: A Listing of known religious Divest and Reinvest efforts. Available at: http://www.greenfaith.org/programs/divest-and-reinvest/ listing-of-known-religious-divestment-efforts (accessed January 31, 2017). The Church of England has divested from coal and tar sands investment.

40. Andrew Brown: Church of England Governing Body Approves Divestment Policy (The Guardian, 2015). Available at: https://www. theguardian.com/environment/2015/jul/14/church-of-englandgoverning-body-approves-divestment-policy (accessed January 31, 2017).

41. Campuses \& Organizations That Have Divested, University of Wisconsin. Available at: http://www.uwosh.edu/es/climate-change/divestment/ the-divested (accessed January 31, 2017).

42. Depending on the severity of warming that occurs by 2100 , losses to global managed assets could range from $\$ 4.2$ trillion in present value terms-The value of Japan's GDP-To triple that, for a $6{ }^{\circ} \mathrm{C}$ rise. See: Economist Intelligence Unit: The Cost of Inaction: Recognizing the Value at Risk from Climate Change (EIU, London, 2015). Available at: https://www. eiuperspectives.economist.com/sites/default/files/The\%20cost\%20 of\%20inaction_0.pdf (accessed January 31, 2017).

43. John Schwartz: Norway Will Divest From Coal in Push Against Climate Change (New York Times, 2015). Available at: http://www.nytimes. com/2015/06/06/science/norway-in-push-against-climate-change-willdivest-from-coal.html (accessed 31 January 2017).

44. Rockefeller Brothers Fund: Divestment Statement (2014). Available at: http://www.rbf.org/about/divestment (accessed January 31, 2017)
45. Wade T. and Driver A.: Rockefeller Family Fund Hits Exxon, Divests From Fossil Fuels (Reuters, 2016). Available at: http://www.reuters.com/article/ us-rockefeller-exxon-mobil-investments-idUSKCN0WP266 (accessed January 31, 2017).

46. Ansar A., Caldecott B., and Tilbury J.: Stranded assets and the fossil fuel divestment campaign: What does divestment mean for the valuation of fossil fuel assets. Stranded assets Programme SSEE Univ. Oxf. Vol. 1 (2013).

47. Glomsrød S. and Wei T.: Business as UNusual: The Implications of Fossil Divestment and Green Bonds for Financial Flows, Economic Growth and Energy Market (February 16, 2016). Available at SSRN: https://ssrn.com/ abstract $=2733423$ or http://dx.doi.org/10.2139/ssrn.2733423

48. Baron R. and Fischer D.: Divestment and Stranded Assets in the LowCarbon Transition (OECD, Paris, 2015).

49. Fossil Free Indexes: The CalPERS Portfolio and Fossil Fuel Reserve-Related CO2 Emissions 2004-2013 (Fossil Free Indexes LLC, 2014). Available at: http://fossilfreeindexes.com/research/calpers-portoflio-financed-co2emissions/ (accessed January 31, 2017).

50. Total of $\$ 38$ million in value. D. Starkman: CalPERS set to divest from thermal-coal companies (Los Angeles Times, 2015). Available at: http:// www.latimes.com/business/la-fi-calpers-divest-20151019-story.html (accessed January 31, 2017).

51. CalPERS to Set Talks With Thermal Coal Companies (CalPERS news release, 2015). Available at: https://www.calpers.ca.gov/page/newsroom/ calpers-news/2015/coal-divestment-statement (accessed January 31, 2017).

52. Author interview with former GDF Suez employee who spoke on condition of anonymity (2016).

53. Blum J.: Dynegy speeds up purchase of 17 former Engie power plants (Houston Chronicle FuelFix, 2016). Available at: http://fuelfix.com/ blog/2016/06/15/dynegy-speeds-up-purchase-of-17-power-plants-fromengie/ (accessed January 31, 2017).

54. Why the ENGIE Group will embark on no new coal-fired power plant projects (Engie Press Release, 2015). Available at: http://www.engie.com/ en/group/opinions/energy-transition-climate/embark-on-no-new-coalfired-power-plant-projects/ (accessed January 31, 2017).

55. Miller J.W. and Jarzemsky M.: Peabody Energy Files for Chapter 11 Bankruptcy Protection (Wall Street Journal, 2016). Available at: http:// www.wsj.com/articles/peabody-energy-files-for-chapter-11-protectionfrom-creditors-1460533760 (accessed January 31, 2017).

56. HSBC: Assessing climate risk: Investors need to know how companies will be affected by climate change (HSBC Press Release, 2016). Available at: http://www.gbm.hsbc.com/insights/responsible-business/assessingclimate-risk (accessed January 31, 2017).

57. US Securities and Exchange Commission: Commission Guidance Regarding Disclosure Related to Climate Change (Interpretive Release, 2010); 17 CFR parts 211, 231, and 241. Available at: https://www.sec.gov/ rules/interp/2010/33-9106.pdf (accessed January 31, 2017).

58. MSCI: 2015 ESG Trends to Watch (MSCI Inc., 2015); pp. 3-5. Available at: https://www.msci.com/documents/10199/6547ff32-d337-4c3a-9f01f8c90f43cb91 (accessed January 31, 2017).

59. Bloomberg Carbon Risk Valuation Tool (2013). Available at: https://www. bloomberg.com/company/announcements/introducing-our-carbon-riskvaluation-tool (accessed January 31, 2017).

60. HSBC: Assessing Climate Risk: Investors Need to Know How Companies Will be Affected by Climate Change (HSBC Press Release, 2016). Available at: http://www.gbm.hsbc.com/insights/responsible-business/assessingclimate-risk (accessed January 31, 2017).

61. Ban Urges Insurance Industry to Take Leadership in Climate Change Response (UN News Center, 2016). Available at: http://www.un.org/apps/news/story. asp?NewsID=53676\#.WEBJIrIrLmF (accessed January 31, 2017).

62. King E.: Insurers Told to Pull Cover from Coal Companies (Climate Home, 2015). Available at: http://www.climatechangenews.com/2015/03/25/ insurers-told-to-pull-cover-from-coal-companies/ (accessed 31 January 2017).

63. U.S. Insurance sector Heavily Invested in fossil fuel sectors, despite growing Awareness of climate change risks (Ceres Press Release, 2016). Available at: https://www.ceres.org/press/press-releases/ceresreport-u.s.-insurance-sector-heavily-invested-in-fossil-fuel-sectors-despitegrowing-awareness-of-climate-change-risks (accessed January 31, 2017). 
64. California Insurance Commission: Climate Risk Carbon Initiative Questions \& Answers (2016). Available at: http://www.insurance.ca.gov/ 0250-insurers/0300-insurers/0100-applications/ci/upload/ClimateRisk-Carbon-Initiative-Questions-4.pdf (accessed January 31, 2017).

65. Patel T.: Fossil-Fuel Divestment Gains Momentum with Axa Selling Coal (Bloomberg, 2015). Available at: https://www.bloomberg.com/news/ articles/2015-05-22/fossil-fuel-divestment-picks-up-momentum-with-axaselling-coal (accessed January 31, 2017).

66. Climate Protection Will Become Part of Core Business (Allianz SE Statement, 2015). Available at: https://www.allianz.com/en/press/news/financials/ stakes_investments/151126_climate-protection-will-become-part-of-corebusiness (accessed January 31, 2017).

67. Export-Import Bank of the United States: Annex A: International Environmental and Social Guidelines (2016). Available at: http://www. exim.gov/policies/ex-im-bank-and-the-environment/internationalenvironmental-and-social-guidelines (accessed January 31, 2017).

68. See, for example, BankTrack's "Top Twenty Coal Banks" Ranking. Available at: http://coalbanks.org/\#score (accessed January 31, 2017).

69. Citigroup: Sector Briefs: Oil Sands (2013). Available at: http://www. citigroup.com/citi/environment/data/1160844_Sector_Brief_Oil_Sands. pdf (accessed January 31, 2017).

70. Corkery M.: As Coal's Future Grows Murkier, Banks Pull Financing (New York Times, 2016). Available at: http://www.nytimes. com/2016/03/21/business/dealbook/as-coals-future-grows-murkierbanks-pull-financing.html (accessed January 31, 2017).

71. Teixeira M.: Brazil Development Bank Scraps Financing for Coal-Fired Plants (Reuters, 2016). Available at: http://www.reuters.com/article/ brazil-power-financing-idUSL2N1C913N (accessed January 31, 2017).

72. Natural Resources Defense Council: Coal Financing and Japan: Actions Speak Louder than Words (Natural Resources Defense Council Press Release, 2016). Available at: https://www.nrdc.org/experts/jake-schmidt/ coal-financing-and-japan-actions-speak-louder-words (accessed January 31, 2017).

73. BankTrack: Banking on Coal 2014. Available at: http://www.banktrack. org/download/banking_on_coal_2014_pdf/banking_on_coal_2014.pdf (accessed January 31, 2017).

74. M. Elgin-Cossart and M. Hart: China's new international financing institutions (Center for American Progress Policy Paper, 2015). Available at: https://www.americanprogress.org/issues/security/ reports/2015/09/22/121668/chinas-new-international-financinginstitutions/ (accessed January 31, 2017).

75. Citi GPS: Energy Darwinism II: Why a Low Carbon Future Doesn't Have to Cost the Earth (Citicorp Global Perspectives \& Solutions, 2015); p. 83. Available at: https://www.privatebank.citibank.com/home/fresh-insight/ gps-energy-darwinism.html (accessed January 31, 2017).

76. Kepler Cheuvreux: Stranded Assets, Fossilized Reserves (2014). Available at: https://www.keplercheuvreux.com/pdf/research/eg_eg_253208.pdf (accessed January 31, 2017).

77. Pfeiffer A., Millar R., Hepburn C., and Beinhocker E.: The " $2{ }^{\circ} \mathrm{C}$ capital stock" for electricity generation: Committed cumulative carbon emissions from the electricity generation sector and the transition to a green economy. Appl. Energy 179, 1395 (2016).

78. Birol F.: Energy Investment for Global Growth. Slide presentation, G-7 energy ministerial meeting, Japan (2016). Available at: https://www.iea. org/newsroomandevents/speeches/160501_G7EnergyMinisterial_slides. pdf (accessed January 31, 2017).

79. International Energy Agency:Special Report: World Energy Investment Outlook (2014); p. 43. Available at: https://www.iea.org/publications/ freepublications/publication/WEIO2014.pdf (accessed January 31, 2017).

80. Caldecott B., Dericks G., Tulloch D.J., Kruitwagen L., and Kok I.: Stranded Assets and Thermal Coal in Japan: An Analysis of Environment-Related Risk Exposure (Smith School of Enterprise and the Environment, Oxford, 2016).
81. Carbon Tracker Initiative: Unburnable Carbon 2013: Wasted Capital and Stranded Assets (2013). Available at: http://www.carbontracker.org/ report/unburnable-carbon-wasted-capital-and-stranded-assets (accessed January 31, 2017).

82. See, for example, Crooks E.: Analysts Dismiss 'Carbon Bubble' Warning (Financial Times, 2016). Available at: https://www.ft.com/content/ 9954e072-9587-11e6-a80e-bcd69f323a8b Also see: J. McMahon: 'What Carbon Bubble?' Says Oil Company Economist (Forbes, 2016). Available at: http://www.forbes.com/sites/jeffmcmahon/2016/03/17/ what-carbon-bubble-says-oil-company-economist/ (accessed January 31, 2017).

83. Yergin D. and Pravettoni E.: Deflating the carbon bubble. IHS Markit Research Report (2016). Available at: https://www.ihs.com/Info/1016/ strategic-report-systemic-risk.html (accessed January 31, 2017).

84. Mathieu C.: Carbon Risk and the Fossil Fuel Industry. Research Paper, IFRI Center for Energy (2015); pp. 7-8.

85. See, for example: What is Geoengineering? Oxford geoengineering Program. Available at: http://www.geoengineering.ox.ac.uk/what-isgeoengineering/what-is-geoengineering (accessed January 31, 2017).

86. A large volume of literature exists on this subject. See for example: E.A. Posner and C.R. Sunstein: Climate change justice. Geo LJ96, 1565 (2007).

87. D.A. Farber: Basic compensation for victims of climate change. Univ. Pa. Law Rev. 155(6), 1605 (2007).

88. K. Healy and J.M. Tapick: Climate Change: It's not just a policy issue for corporate Counsel-It's a legal problem' (2004). Columbia J. Environ. Law 29, 89 (n.d.).

89. Hancock E.E.: Red dawn, blue thunder, purple rain: Corporate risk of liability for global climate change and the SEC disclosure dilemma. Geo Intl Envtl Rev 17, 233 (2004).

90. Grossman D.A.: Warming up to a not-so-radical idea: tort-based climate change litigation. Colum. J. Envtl. L. 28, 1 (2003).

91. United States District Court for the District of Oregon Eugene Division: Case No. 6:15-cv-01517-TC (D. Or. Nov. 10, 2016) https://casetext.com/ case/juliana-v-united-states-1.

92. Heidari N. and Pearce J.M.: A review of greenhouse gas emission liabilities as the value of renewable energy for mitigating lawsuits for climate change related damages. Renewable and Sustainable Energy Reviews 55, 899-908 (2016).

93. Allen M.: Liability for climate change. Nature 421(6926), 891 (2003).

94. Sinn H-W.: Public policies against global warming: A supply side approach. Int. Tax Public Finance 15(4), 360 (2008).

95. This is a simplification of the Saudi strategy. Saudi officials take many aspects of oil markets into account. Climate factors may be outweighed by other interests, including price. In fact, the kingdom agreed to cut nearly 500,000 barrels of oil production a day in December 2016, amid a widespread agreement among producers. Further, even "unburnable" oil retains markets in petrochemicals, lubricants, etc.

96. Estimate from M. O'Hanlon: Energy Security: Economics, Politics, Strategies, and Implications, edited by Carlos Pascual and Jonathan Elkind (Brookings, Washington, 2010); pp. 59-72.

97. Verbruggen A. and Van de Graaf T.: The geopolitics of oil in a carbonconstrained world. IAEE Energy Forum 2(2), 21 (2015).

98. Fouquet R.: The slow search for solutions: Lessons from historical energy transitions by sector and service. Energy Policy 38(11), 6586 (2010).

99. Patel M., Neelis M., Gielen D., Olivier J., Simmons T., and Theunis J.: Carbon dioxide emissions from non-energy use of fossil fuels: Summary of key issues and conclusions from the country analyses. Resour. Conserv. Recycl. 45(3), 195 (2005).

100. Note that Exxon's petrochemical ventures include joint ventures with Saudi Aramco, the most efficient and technologically proficient of the world's national oil companies. See: P.R. Hartley and K.B. Medlock, III: Changes in the operational efficiency of national oil companies. Energy J. 34(2), 27 (2013). 